\title{
CELULARES: UM "PRESENTE DO CÉU” PARA MÃES DE JOVENS
}

\author{
Ana Maria Nicolaci-da-Costa ${ }^{1}$ \\ Pontifícia Universidade Católica do Rio de Janeiro, Rio de Janeiro, Brasil
}

RESUMO: Pesquisas realizadas em diferentes partes do mundo mostram que pais e mães equipam seus filhos jovens com celulares como uma forma de garantir sua segurança enquanto fazem as primeiras incursões por um mundo visto como cada vez mais perigoso. Os resultados de uma pesquisa realizada com mães de jovens cariocas entre 18 e 25 anos de idade revelam, no entanto, que essa pode não ser a única razão para que os filhos recebam celulares de presente de seus pais. Embora a preocupação com a segurança dos filhos fosse constantemente mencionada por todas as mães entrevistadas, foi sobretudo à sua própria segurança - usada com o significado de tranqüilidade, sossego, paz de espírito, etc. - que essas mães fizeram referência. O celular é, para elas, uma importante fonte de alívio da angústia de não saber onde estão os filhos.

PALAVRAS-CHAVE: Celulares; mães; jovens; segurança; tranqüilidade.

\section{CELL PHONES: A "GOD-GIVEN GIFT" FOR MOTHERS OF YOUNGSTERS}

ABSTRACT: Investigations conducted in different parts of the world show that parents equip their young children with cell phones in an attempt to enhance their safety while they independently explore a world perceived as progressively dangerous. Results from a study carried out in Rio de Janeiro with mothers of 18 to 25 year old youngsters, however, reveal that this may not be the sole reason for such parental behavior. Even though all interviewees constantly mentioned worries about their children's safety, above all these mothers were mainly referring to their own safety - used with the meaning of tranquility, calmness, peace of mind, etc. For them, the cell phone is an important source of relief from the anguish of not knowing where their children are.

KEYWORDS: Cell phones; mothers; youngsters; safety; peace of mind.

Sabemos que há muitos milhões de usuários de celulares ao redor do mundo. Sabemos, também, que a telefonia celular conquistou esses milhões de usuários muito rapidamente, ou seja, nos últimos dez anos. Sabemos, ainda, que as vidas desses usuários vêm mudando em ritmo acelerado por conta da telefonia celular. Apesar de tudo isso, como assinalam Katz e Aakhus (2002), há um relativo vazio de pesquisas acadêmicas sobre os impactos sociais e pessoais da difusão dos celulares.

De fato, os estudos levados a cabo sobre os impactos da telefonia celular nas ciências humanas e sociais ainda são bastante esparsos. São, também, de difícil acesso, na medida em que freqüentemente são publicados fora do tradicional circuito anglo-saxão (muitos são, inclusive, publicados em línguas tão pouco conhecidas quanto as escandinavas ou orientais). Neste circuito, tem-se acesso principalmente às investigações divulgadas em publicações - não muito comuns - como aquelas organizadas por Castells, Fernández-Ardèvol, Qiu e Sei (2007); Gottlieb e McLelland (2003); Ito, Okabe e Matsuda (2005); Katz e Aakhus (2002). É, no entanto, importante observar que, apesar de escassa, essa literatura tem seu alcance em grande parte compensado pelas diferentes origens culturais das pesquisas que a compõem. Estas são tão diversas quanto as culturas dos países que ocupam as posições de ponta no desenvolvimento da telefonia móvel: os países escandinavos (principalmente a Noruega e a Finlândia) e alguns países orientais (entre os quais se destaca o Japão).

Tal compensação é visível no que tange à noção de segurança. Neste caso, é surpreendente o consenso (raro nas ciências humanas e sociais, tão sensíveis a variações culturais) que vigora entre diferentes pesquisadores. Trabalhando independentemente, esses pesquisadores de diversas partes do mundo constataram que, desde o seu surgimento, os telefones celulares vêm desenvolvendo uma íntima associação com concepções de segurança (estas, sim, podendo variar de uma cultura para outra). Tal associação se traduz em um mesmo sentimento genérico que parece atravessar fronteiras de países e continentes: o de que os celulares tornam nossas vidas mais seguras em um mundo no qual a segurança se tornou um bem raro (Ling, 2004).

A associação celular-segurança, segundo os mesmos estudiosos, é especialmente forte no que diz respeito aos jovens (na realidade, a maior parte dos estudos sobre essa associação se refere a crianças e, principalmente, adolescentes). Baseados em resultados de investigações realizadas em diferentes lugares, esses pesquisadores revelam que a sensação de segurança que os celulares instilam provém do fato de que estes servem de ferramentas de auto- 
proteção para os jovens (que podem pedir socorro ou ajuda a qualquer hora) e de monitoramento dos filhos para os pais.

Trocando em miúdos, neste mundo cheio de riscos, incertezas e perigos, a tradicional preocupação de pais e mães com seus filhos jovens se tornou ainda maior. Por esse motivo, jovens que começam a ter experiências independentes são imediatamente equipados com telefones celulares. Isso acontece, por exemplo, no Japão (Habuchi, 2005; Miyaki, 2005; Tomita, 2005), na Noruega (Ling, 2004; Ling \& Yttri, 2002), na Inglaterra (Nafus \& Tracey, 2002) e em outros países da Europa, a exemplo da Espanha, França e República Tcheca (Ling, 2004). Muito provavelmente, acontece também em várias outras partes do mundo sobre as quais ainda não há dados de pesquisa divulgados.

\section{O Caso Brasileiro}

O quadro brasileiro apresenta algumas semelhanças com o internacional. Em primeiro lugar, uma busca nas principais bases de dados nacionais revela que, também no Brasil, existe um vácuo de investigações acadêmicas sobre os impactos sociais e pessoais da difusão da telefonia celular.

A segunda semelhança que existe entre o que se passa no Brasil e no resto do mundo diz respeito à associação dos celulares à segurança no que tange aos jovens. A observação a olho nu - extremamente importante em épocas de mudança acelerada como a que estamos presenciando (Nicolaci-da-Costa, 2002) - é complementada pelos poucos resultados de pesquisa sobre o uso de celulares por jovens e seus pais no nosso país. Vejamos.

Em uma pesquisa realizada na cidade do Rio de Janeiro sobre o uso que faziam de seus celulares jovens universitários cujas idades variavam entre 18 e 25 (Nicolacida-Costa, 2004a, 2004b), essa associação apareceu de forma nítida. Embora já não fossem adolescentes como na maior parte dos estudos mencionados anteriormente, os entrevistados revelaram que, preocupados com sua segurança, seus pais lhes haviam presenteado com celulares para que pudessem entrar em contato ou pedir ajuda em casos de emergência. Um outro resultado - que se revelou relacionado ao primeiro - emergiu com clareza da mesma pesquisa: quase todos esses jovens adultos reclamavam muito que suas mães (praticamente não havia menção aos pais) os controlavam 24 horas por dia através dos celulares.

Para tentar compreender este último achado, foi realizado um novo estudo. Essa nova investigação tinha como objetivo conhecer o uso que mães faziam de seus próprios celulares. Almejava também verificar se deste uso fazia parte o controle dos filhos. Como veremos em maior detalhe adiante, de modo a possibilitar comparações com a pesquisa anterior, foram entrevistadas mães de jovens que tinham o mesmo perfil que os jovens que haviam participado da primeira pesquisa (Nicolaci-da-Costa, 2006).

Os resultados deste segundo estudo mostraram claramente que as mães entrevistadas de fato usavam seus celulares e os dos filhos para monitorá-los à distância, muitas o fazendo 24 horas por dia. Essas mães chegavam mesmo a admitir abertamente que seu intuito era o de "controlá-los entre aspas". Tal controle - ficou evidente - não objetivava coagir ou proibir. Objetivava, sim, fazer com que as mães tivessem ciência de como e onde os filhos estavam, com quem estavam, a que horas iam voltar para casa, etc. $\mathrm{Ou}$ seja, controle e segurança mostraram estar intimamente vinculados (Nicolaci-da-Costa, 2006). Os depoimentos coletados, entretanto, não deixavam imediatamente aparente o que essas mães concebiam como segurança. Além disso, nesses mesmos depoimentos foram encontrados indícios de que outras motivações que não a segurança levavam-nas a exercer esse controle, próximo embora à distância, sobre os passos dos filhos.

Essas indagações e suspeitas determinaram a necessidade de re-examinar as transcrições do material coletado e já analisado no que diz respeito ao controle. Esse reexame visava buscar: (a) o que exatamente essas mães viam como segurança, e (b) se realmente havia outros motivos para esse comportamento controlador que pudessem estar sendo encobertos pelos discursos do controle e da segurança.

Antes, porém, de discorrer sobre esse re-exame, cabe apresentar ao leitor deste artigo como o Método de Explicitação do Discurso Subjacente - MEDS (Nicolaci-daCosta, 2007) foi utilizado para gerar os depoimentos em questão. Isso, no entanto, será feito de forma breve, pois uma descrição detalhada poderá ser encontrada em Nicolacida-Costa (2006).

\section{Origem dos Resultados a serem Re-Analisados}

\section{Sobre as Participantes}

Dado que, como já foi mencionado, o objetivo original desta segunda pesquisa era o de conhecer a fundo como mães de jovens adultos usavam seus celulares, foi necessário que a investigação se concentrasse em torno de um pequeno grupo de mulheres que tivessem algumas características básicas em comum (Nicolaci-da-Costa, 2007).

Foram, portanto, estabelecidos os seguintes critérios para o recrutamento das participantes.

1. Para que pudesse emergir uma perspectiva complementar àquela dos jovens da primeira pesquisa, todas deveriam ter filhos com o mesmo perfil e faixa etária destes (ou seja, seus filhos deveriam ser universitários com idades entre 18 e 25 anos). 
2. Tal como os jovens na primeira pesquisa, todas as participantes deveriam pertencer às camadas médias da cidade do Rio de Janeiro.

3. Todas deveriam morar com os filhos, pois o que estava sendo investigado era a comunicação cotidiana entre mães e os filhos que ainda estavam sob sua guarda.

4. Todas deveriam ter celular próprio há no mínimo um ano, dado que alguma experiência é imprescindível para que a comunicação aconteça de forma eficaz e rotineira.

Com base nesses critérios, foram recrutadas vinte participantes a partir de indicações de conhecidos dos pesquisadores. Suas idades variavam entre 41 e 55 anos. Apenas 9 ainda viviam com os pais de seus filhos. Outras 9 eram divorciadas ou separadas e 2 eram viúvas. Tinham entre 1 e 3 filhos cada. Seu tempo de uso de celulares variava entre 2 e 10 anos (somente uma entrevistada tinha celular há 2 anos, e pelo menos cinco já possuíam celulares há mais de 8 anos à época da entrevista). A todas foram atribuídos nomes fictícios para a preservação de seu anonimato.

\section{Coleta de Dados}

Os dados foram coletados por meio de entrevistas individuais de, em média, cerca de uma hora de duração. De modo a que se assemelhassem a uma conversa informal e descontraída - o que era de fundamental importância para que as entrevistadas se sentissem à vontade para revelar suas opiniões, pensamentos e sentimentos (Labov, 1972; Nicolaci-da-Costa, 2007) - todas as entrevistas foram realizadas em locais escolhidos pelas próprias participantes.

Inicialmente, eram coletados dados objetivos de cada uma das entrevistadas: sua idade, ocupação, estado civil, número de filhos, idade dos filhos, número de pessoas com quem morava (e quem eram essas pessoas), tempo de uso de um celular próprio e número de filhos que tinham celulares.

A seguir, tinha início a coleta de dados subjetivos. Esta era realizada a partir de um roteiro, construído de acordo com as diretrizes do MEDS (Nicolaci-da-Costa, 2007). Esse roteiro, que tinha como base aquele usado nas entrevistas com os jovens, era composto de 40 itens principais a partir dos quais eram formuladas perguntas durante a própria entrevista. Este procedimento objetivava manter as características de uma conversa natural, evitando que as perguntas fossem lidas e, conseqüentemente, soassem artificiais (Nicolaci-da-Costa, 2007). Com o mesmo objetivo de manter a naturalidade e a descontração, procurava-se preservar o fluxo do raciocínio das entrevistadas. Por essa razão, a ordem dos itens podia mudar de uma entrevista para outra (sendo que itens abordados espontaneamente pelas entrevistadas sequer necessitavam ser mencionados pelos entrevistadores). A maior parte desse roteiro era composta de itens/perguntas abertos (que permitem qualquer tipo de resposta). Quando necessários, eram incluídos itens/perguntas fechados (cujas respostas são sim e não), sempre seguidos de perguntas de aprofundamento, como: "por quê?"; "como?"; "onde?", "dá para explicar melhor?". Não havia nenhuma pergunta sobre controle ou segurança, pois a experiência mostra que $o$ que quer que seja importante para os entrevistados sempre aparece espontaneamente em seus discursos. Os itens/perguntas do roteiro eram agrupados em blocos temáticos (o roteiro completo pode ser examinado em Nicolaci-daCosta, 2006). Estes versavam sobre os seguintes tópicos.

1. O uso que essas mulheres faziam de seus celulares: quando os haviam comprado, como os usavam, qual a maior utilidade dos celulares para elas, como se sentiam com a possibilidade de serem encontradas a qualquer hora, como se sentiam com a possibilidade de encontrar os outros (principalmente os filhos) a qualquer hora, etc.

2. As diferenças entre o telefone fixo e o celular: qual telefone usavam mais (por quê), em qual recebiam mais ligações (por quê), de quem eram essas ligações, de qual telefone ligavam mais, etc.

3. A comunicação na família: quem tinha celular em sua família, se haviam comprado ou haviam ganho (se haviam ganho, quem tinha dado e por quê), como era a comunicação entre os membros da família, quem ligava mais para quem (por quê), com que frequiência falavam com seus filhos durante o dia, para que se falavam, etc.

4. Como a entrevistada se relacionava com o seu celular: quais as mudanças positivas que o celular havia gerado na sua vida (por quê), quais as mudanças negativas (por quê), se gostaria de voltar à vida sem celular (por quê).

5. Privacidade e intimidade: o que era privacidade para a entrevistada, se havia mudado alguma coisa em sua privacidade com o uso do celular, o que era intimidade para a entrevistada, como ficava a intimidade com o uso do celular.

\section{A Re-Análise das Entrevistas}

Todas as entrevistas, já transcritas na íntegra para a análise do controle materno, foram re-submetidas às duas etapas que compõem a análise qualitativa de discurso, tal como descrita pelo MEDS (Nicolaci-da-Costa, 2007). Na primeira dessas etapas, como de praxe, foram feitas comparações inter-participantes. Para tanto, foram reunidas todas as respostas de todas as participantes a cada um dos itens/perguntas de modo que pudessem ser identificadas as recorrências nos depoimentos gerados por cada um desses itens/perguntas no que diz respeito à segurança. Já 
na segunda etapa - a da análise intra-participantes -, as respostas de cada uma das entrevistadas foram analisadas como um único conjunto dentro do qual se procurou detectar possíveis conflitos de opiniões, inconsistências entre respostas, sentimentos contraditórios, etc. no que diz respeito à segurança. Dado que esses tipos de conflitos ou inconsistências não foram detectados, os resultados que se seguem tiveram origem somente na análise interparticipantes.

\section{Resultados da Re-Análise}

A re-análise dos depoimentos gerados por esta segunda pesquisa se mostrou bastante produtiva quando inserida no contexto dos estudos por nós realizados e mencionados anteriormente. Neste momento, portanto, cabe rememorar alguns dos resultados destes.

Primeiramente, há que retomar os dois resultados produzidos pela pesquisa com os jovens (Nicolaci-da-Costa, 2004a, 2004b) já mencionados na introdução. Ambos são de particular interesse para a presente análise. Recordando, o primeiro se refere ao fato de praticamente todos os jovens entrevistados haverem revelado ter ganho seus celulares de seus pais para que pudessem pedir ajuda ou socorro em casos de emergência. Já o segundo diz respeito à sua insatisfação com o controle que esses mesmos celulares permitiam que suas mães (lembremo-nos de que raramente se referiam aos pais) sobre eles exercessem 24 horas por dia.

Em segundo lugar, é importante que sejam revisitados os achados sobre controle gerados pela pesquisa realizada com as mães. Esta, vale recordar, revelou que os jovens da primeira pesquisa provavelmente tinham razões para reclamar. Todas as mães entrevistadas admitiram espontânea e abertamente que controlavam seus filhos via celulares. Faziam, porém, uma distinção entre o controle normativo ou coercitivo ao qual elas próprias haviam sido submetidas quando jovens e o "controle entre aspas" que exerciam sobre os filhos. Segundo elas, este último tinha apenas a finalidade de colocá-las a par de onde eles estavam, do que estavam fazendo, de seus movimentos, de sua segurança (curiosamente, como veremos adiante, essas mães também não faziam referência aos pais).

A atual re-análise desse mesmo material, como poderá ser constatado abaixo, permite que agora possamos oferecer algumas alternativas de resposta para questões levantadas por alguns pronunciamentos feitos pelas mães. $\mathrm{O}$ principal deles diz respeito à nova concepção de um controle "de saber o que está acontecendo", que permite que elas se sintam velando pela "segurança" dos filhos enquanto eles se movimentam pela cidade durante o dia e, principalmente, ao longo da noite. Acreditariam essas mães que poderiam de fato garantir a segurança de seus filhos à distância? Ou será que, tal como sua concepção de controle (que já havia se distanciado da tradicional), sua concepção de segurança também estava sofrendo transformações? O que essas mulheres encaravam como segurança?

\section{$O$ que as Entrevistadas dizem sobre Segurança}

Tanto a revisão da literatura especializada quanto os resultados da pesquisa por nós realizada com jovens universitários apontavam a segurança dos filhos diante de situações inesperadas e potencialmente perigosas como uma das principais razões para a compra de telefones celulares pelos pais.

A presente re-análise, entretanto, mostrou que os resultados gerados pela pesquisa com as mães não foram tão claros. Explicitamente foram poucas as mães que admitiram haver comprado os celulares de seus filhos para a segurança deles. Quando o fizeram, de fato relacionaram essa segurança principalmente a casos de emergência como o carro enguiçar, um pneu furar, haver um acidente... Seguem-se dois exemplos.

Grace Costa (comerciante, 48 anos de idade) diz que deu um celular para sua filha porque “... [ela] dirige, às vezes viaja, pega o carro sozinha à noite, né? Então acho que o celular traz mais segurança. Se o carro quebra, ela pode ligar". Nadia Carvalho (administradora, 48 anos) dá um exemplo semelhante, porém mais concreto: "Ela [a filha] bateu com o carro no sábado. Eu tava até viajando, ela pegou e ligou pro tio".

Uma outra forma de se referirem explicitamente à segurança dos filhos está associada à crença de que estes estão mais seguros quando de posse de seus celulares porque podem receber orientações delas.

Tânia de Castro (professora, 53 anos) é uma das mães que se referem à segurança do filho dessa forma. Esclarece que liga para ele para alertá-lo sobre perigos como: “... tá caindo um temporal e eu sei que ele tá na rua. [Digo] para ele evitar vir para casa. Tá num lugar abrigado, evita vir. Tá tudo cheio...” Outra mãe que faz afirmações análogas é Joana Pinto (engenheira, 53 anos). Esta revela: "Teve um dia que eu estava deitada e ouvi um carro bater aqui na esquina. Eu sabia que o A. chegava perto daquela hora, então liguei pra ele e avisei. Foi a primeira coisa que eu fiz."

Essas referências à função dos celulares como garantia de segurança para os filhos estavam presentes em poucos depoimentos. A temática da segurança, no entanto, estava presente em todas as entrevistas. Na esmagadora maioria das vezes, contudo, embora deixassem claro que estavam sempre preocupadas com os filhos, as mães surpreendentemente afirmavam que os celulares geravam segurança para elas mesmas.

De fato, em seu discurso, insistente e consistentemente empregavam a palavra "segurança" em contextos nos quais 
era evidente que se referiam aos celulares como aparelhos que lhes propiciavam tranqüilidade, paz, sossego, descanso, alivio, etc. Para elas, como tal uso indica, o campo semântico da palavra "segurança" já havia sofrido alterações. Ao menos em parte, essa palavra já havia perdido seu antigo significado de proteção ou garantia contra perigos e incorporado outros significados, desta feita associados aos campos semânticos da tranqüilidade, paz de espírito e sentimentos análogos. Examinemos alguns exemplos.

Comecemos pelo de Raquel Dias (economista, 46 anos), que revela como o celular aplaca sua angústia:

Encontrar os filhos é importantíssimo por conta da segurança... O meu objetivo primeiro, quando eu dei o celular pros meus filhos, foi de poder encontrá-los. [Porque] no momento em que, e isso já aconteceu várias vezes comigo, eu acordar às 3 horas da manhã extremamente angustiada... eu passo a mão no telefone e saio ligando pra todo mundo: 'ah onde é que você tá? Tá tudo bem?'

Marcela Andrade (economista, 46 anos) e Elizabeth Dantas (comerciária, "40 e tal...") revelam ter opiniões e sentimentos análogos aos de Raquel. Marcela revela:

é muito raro eu ligar. Por exemplo, a C... sai pros programas dela. Muito raro eu ligar, 'C., onde você tá?'. Não, mas eu tenho a segurança comigo que ela está com celular, e que numa necessidade eu vou saber onde ela está...

\section{E Elizabeth explicita:}

[Com o celular] eu fico bem mais tranqüila, porque eu sei que posso falar com ele [o filho] ou ela [a filha] a qualquer hora... Minha preocupação é com os dois, né? Dá tranquiilidade, acho uma maior segurança, você saber...

Nestes depoimentos, alguns dentre vários semelhantes, essas três mães falam a respeito da sua constante preocupação com a segurança de seus filhos indiretamente, ao falar sobre a segurança que os celulares trouxeram para suas próprias vidas. Estão sempre preocupadas com seus filhos quando estes estão fora de casa, mas os celulares aliviam essa preocupação.

Muitas entrevistadas se referem à violência que existe na cidade do Rio de Janeiro nos dias de hoje como a principal causa de sua constante inquietação. Esta se torna ainda maior ao longo da madrugada, pois os filhos nunca têm programação fixa quando saem para a night (Almeida \& Tracy, 2003).

Marcela Andrade (dona-de-casa, 54 anos) afirma que os celulares são importantes para saber onde os filhos estão porque:

de madrugada, com essa violência que está aí... se a A. [a filha] demora a chegar, ou ele [o filho] demora a chegar, como é que eu vou encontrar? Se eu não tenho um telefone de contato, como? Tendo o celular eu já vou encontrar eles aonde eles estiverem, num ônibus, num carro, aonde eles estiverem...

Márcia Amorim (professora, 54 anos) também se refere ao medo que tem da filha ser assaltada de madrugada:

Nosso sistema de garagem é muito ruim. Eles custam a abrir. Já teve pessoas aqui do prédio que foram assaltadas ali na entrada. [Quando ela está chegando], ela me liga, 'tô chegando'. Aí eu desço, ou então falo no interfone com o rapaz, 'abre agora'...

Ludmila Alves (professora, 43 anos), por seu turno, afirma ligar para as filhas "Pra saber onde elas estão, essa coisa de rotina. Muda tudo [a programação delas]. Aí eu fico preocupada. Essa cidade é violenta, né?”

Outras mães se referem de forma mais genérica às incertezas dos nossos dias. Luciana da Silva (psicóloga, 55 anos), por exemplo, diz que o celular a deixa "menos insegura nessa vida louca que a gente leva, né, de incertezas....'. E Regina Ribeiro (fonoaudióloga, 46 anos) diz se sentir "bem mais segura [em relação aos filhos]... nesse mundo meio doido, né? Assim, 'ah! tá onde?', 'tô no trânsito', 'tô chegando em casa'. Então isso me dá mais segurança."

A re-análise dos depoimentos das mães entrevistadas detecta, porém, um outro motivo, para a compreensão do qual corroboram os resultados da pesquisa com os jovens. Tais depoimentos e resultados indicam que essa grande preocupação com os filhos, que todas as entrevistadas revelam ter, não é dividida com os pais destes.

Várias (a maioria) afirmam abertamente que este monitoramento da segurança dos filhos é um papel de mãe. As demais não chegam a fazer tal afirmação abertamente, mas deixam isso claro ao longo de seus depoimentos. $\mathrm{E}$, tal como os jovens da primeira pesquisa raramente faziam referência a seus pais, as mães entrevistadas nesta pesquisa também não fazem referência aos pais de seus filhos no que diz respeito ao controle da segurança destes (quando fazem referência aos pais ou é para reclamar que eles não gostam de usar celulares ou para dizer que eles não se preocupam tanto quanto elas). Examinemos alguns depoimentos.

Grace Costa (comerciante, 48 anos) diz que deixa seu celular sempre por perto:

Se as meninas me ligam porque aconteceu alguma coisa e elas precisam falar comigo, eu não ouvir pode ser um problema. Até elas falarem com outra pessoa... E nem sempre outra pessoa vai poder resolver. Isso é papel de mãe mesmo.

Luciana da Silva (psicóloga, 55 anos) afirma ligar com relativa frequiência para o filho porque: "Mãe é mãe. 
Mãe controla, mãe é preocupada (rindo muito). Sua mãe [da entrevistadora] não te liga sempre?".

Rafaela Carneiro (administradora, 45 anos) confirma o que Grace e Luciana disseram. Diz: "Eu acho [o celular] bárbaro... Eu sendo uma mãe divorciada, tô sempre tomando conta das minhas filhas, quer dizer, entre aspas, né? Eu posso saber onde elas estão, onde é que não estão. Eu acho maravilhoso."

Poderíamos pensar que esses depoimentos têm a ver com o fato de que Grace é recasada (não vive com o pai de seus filhos), Luciana é viúva e Rafaela é divorciada. Outros depoimentos com exatamente o mesmo teor foram, no entanto, feitos por várias mulheres que ainda vivem com os pais de seus filhos. Seguem-se alguns exemplos.

Solange Fernandes (aposentada, 54 anos) parece repetir o depoimento de Luciana. Ela usa seu celular: "Para para saber se estão bem. Mais essa preocupação de mãe."

Márcia Amorim (professora, 54 anos) fala de uma "ansiedade de mãe", enquanto Nádia Carvalho (administradora, 48 anos) diz que mantém o celular sempre ligado para sua tranqüilidade pessoal e, dirigindo-se à entrevistadora complementa: "Um dia você vai ser mãe!". Ambas também vivem com os pais de seus filhos.

Vivendo com seus filhos, sozinhas ou acompanhadas dos pais destes, parece que nossas entrevistadas vêm como exclusivamente sua a tarefa de saber onde e como eles estão.

Uma das entrevistadas, Tânia de Castro (professora, 53 anos), chega fazer referência explícita a essa preocupação materna como sendo uma característica de gênero: "Eu acho que é aquela preocupação de mulher, né? Os homens, eu acho que são mais desligados...”.

Fica claro, ainda, nos depoimentos de todas as entrevistadas, que o peso dessa preocupação era percebido como insuportável antes do advento dos celulares. Elas expressam isso de várias formas.

Primeiramente, quando perguntadas se gostariam de voltar à vida sem celulares, a maioria responde negativamente (muito embora várias admitam que só sabem usar seus celulares como telefones de longo alcance; Nicolacida-Costa, 2006). São poucas aquelas que acham que poderiam prescindir dos celulares nos dias de hoje. Algumas dizem que gostariam de voltar a viver uma vida tranqüila, na qual não houvesse necessidade de celulares, mas que no mundo atual celular é muito bem-vindo.

Solange Fernandes (aposentada, 54 anos), por exemplo, acha sensacional poder encontrar os filhos para aliviar sua "preocupação de mãe". Quando lhe é colocada a pergunta sobre se gostaria de voltar à vida sem celular, reage prontamente: "Imagina!!! Não queria mesmo!".

Grace Costa (comerciante, 48 anos) tem opinião análoga. Diz que gostaria de: voltar à vida de antigamente... àquele sossego. [Então, havia] mais tranqüilidade, menos necessidade de trocar tantas informações. Nesse mundo o celular não iria fazer tanta falta, mas no mundo de hoje... o celular caiu do céu como um grande presente.

Luciana da Silva (psicóloga, 55 anos) também não gostaria de voltar no tempo. Para ela o celular foi uma "benção". Explica:

Quando meu filho era adolescente e não existia celular eu vivia, 'meu Deus, cadê, onde está?'... Hoje em dia acabou esse problema... eu acho até pelo alívio que deu, 'puxa agora nunca mais eu vou padecer no paraíso', daquela maneira que era antes [Saber que posso entrar em contatol já dá um certo alívio, né?

Estes são apenas alguns exemplos de muitos depoimentos semelhantes. Tomando emprestadas as palavras de Márcia Amorim (professora, 54 anos), para praticamente todas as entrevistadas, o celular "veio num momento muito bom". Tal consenso resulta do fato de que praticamente todas acham que o celular lhes proporcionou alívio, tranquiilidade, sossego, calma. Podem dormir. Acabou aquela de "padecer no paraíso". Solange Fernandes (aposentada, 54 anos) explicita bem esse sentimento: "É um alívio, quando consigo falar. Aí... pummm vou dormir”.

Outro bom indicador do quanto os celulares transmitem de "segurança" e "tranqüilidade", palavras cujo significado parece ter se tornado intercambiável para a grande maioria das entrevistadas, é a frequiência com que ambas aparecem em praticamente todas as entrevistas. Somente uma mãe não usou nem uma nem a outra.

Por todos esses motivos, muitas são entusiastas. Adoram o celular. Acham o que podem fazer com ele "sensacional", "fantástico", "bárbaro", etc.

Nossa análise, todavia, sugere ainda uma outra razão para tanto entusiasmo. Há indícios de que elas derivam desse papel de cuidadoras o benefício do prolongamento da proximidade cotidiana existente entre elas e seus filhos. A comunicação constante possibilita o que Gergen (2002) chamou de presença ausente; a distância geográfica não mais impede o compartilhamento de experiências.

Márcia Amorim (professora, 54 anos) dá um testemunho nesse sentido quando conta como participou da ida de sua filha ao Rock in Rio:

No Rock in Rio, ela ligava... 'então vai cantar tal, tal pessoa, grava pra mim de tanto a tanto'. [Vocês se falavam muito?] Às vezes, mais por isso, né? É, 'grava, isso assim, pra mim, né'? 'Gravou, saiu bem?' Super gostoso, porque ela queria guardar uma lembrança daquele Rock in Rio...

Elizabeth Dantas (comerciária, "40 e tal...”) e Sílvia Junqueira (professora, 49 anos) também revelam ter expe- 
riências análogas com os filhos. Elizabeth conta que seu filho: "Às vezes... tá na night se divertindo, vendo um show e às vezes ele está ouvindo uma música que eu gosto. Aí ele liga pra mim, 'mãe, olha o que eu estou ouvindo...'. Aí bota para eu ouvir." E Sílvia acha ótimo poder encontrar o filho a qualquer hora em qualquer lugar "Porque... se eu tiver que compartilhar alguma coisa boa, eu posso encontrá-lo em qualquer lugar... e uma coisa ruim também, infelizmente."

Tal compartilhamento de experiências, sentimentos, informações, etc. tem uma consequiência inevitável, um bônus pelo qual essas mães não esperavam e do qual usufruem bastante, muitas provavelmente sem qualquer consciência de seu ineditismo. A julgar pelos depoimentos coletados, os celulares estão gerando, pelo menos nas nossas entrevistadas, uma prazerosa sensação de ainda estarem visceralmente ligadas aos seus filhos, embora estes já sejam adultos. Nas perspicazes palavras de Luciana da Silva (psicóloga, 55 anos), o celular se transformou em um "cordão umbilical tecnológico".

\section{Discussão}

Para que possamos interpretar os resultados que acabam de ser apresentados, torna-se necessário retomar, embora brevemente, uma importante discussão que vem sendo desenvolvida na literatura especializada sobre o papel que o risco ocupa na sociedade contemporânea (Leitão \& Nicolaci-da-Costa, 2004). Seguem-se as linhas mestras do raciocínio que preside essa discussão.

No período moderno, várias garantias e formas de proteção nos davam a sensação de (relativa) segurança. Com a chegada da pós-modernidade ou modernidade tardia, as transformações introduzidas no mundo em que vivemos foram tantas que essas garantias e formas de proteção se tornaram coisas do passado (Bauman, 1997/ 1998, 2000/2001). Em conseqüência, o risco se tornou um aspecto central da nossa vida em sociedade. Tal como na época das grandes navegações, quando foi cunhada a palavra "risco", voltamos a enfrentar aquilo a que ela originalmente se referia. Retornamos à "navegação rumo a águas não cartografadas" (Giddens, 1999/2002, p. 32), ou seja, voltamos a enfrentar o desconhecido.

Longe estão os dias em que os Estados zelavam pelo nosso bem-estar. Longe estão os dias em que os sindicatos eram suficientemente fortes para defender os direitos dos trabalhadores, garantir a estabilidade no emprego e lutar contra o desemprego. Longe estão os dias em que imperava o planejamento a longo prazo e a previsibilidade era possível. Longe estão os dias em que a crença nas grandes narrativas (como, por exemplo, a do marxismo, a da diferença "natural" de gêneros ou a da inferioridade também "natural" das raças) oferecia certezas ou receitas de como nos situarmos no mundo.
As incertezas quanto ao presente e ao futuro; as dúvidas a respeito do melhor caminho a seguir; o desconhecimento de como construir uma carreira, de como ingressar (e se manter) no mercado de trabalho; o desemprego (gerado pela obsolescência de certas atividades frente ao desenvolvimento tecnológico); a vida entre estranhos (resultante do constante deslocamento das populações); os novos tipos de relacionamento e de vida em família; o esgarçamento das antigas formas de coesão social são algumas das características da vida na sociedade contemporânea que vêm sendo registradas não somente por Bauman e Giddens, mas também por outros sociólogos, entre os quais se encontram Beck (1995) e Lyon (2001). A despeito de algumas inevitáveis diferenças nas formas de conceberem a atualidade, todos têm posições convergentes no que diz respeito ao fato de que, nos dias de hoje, vivemos numa "sociedade de risco".

Todos concordam que, numa "sociedade de risco", os infortúnios e inseguranças são gerados pelo próprio processo de modernização. Todos também discorrem sobre diferentes tipos de consequiências pessoais desse novo tipo de dinâmica social. Lyon (2001) ressalta a vigilância à qual somos constantemente submetidos. Giddens (1999/ 2002) destaca a crescente consciência que passamos a ter dos riscos aos quais somos expostos (do efeito estufa às ondas de terrorismo e outras formas de violência). Beck (1995) assinala que, a própria dinâmica da "sociedade de risco" introduz a incerteza, a confusão e a insegurança em todos os nichos de nossa existência. Enquanto isso, Bauman (1997/1998) aponta que passamos a viver permanentemente em uma atmosfera de inquietação, ansiedade e angústia, à qual dá o nome de "atmosfera do medo ambiente".

É neste contexto macro-social, e no mais das vezes internacional, que se inserem as inseguranças, as incertezas, a sensação de desproteção e o medo relativos a contextos sociais específicos. Os homens e mulheres contemporâneos têm, portanto, pelo menos dois níveis nos quais suas apreensões são geradas: o macro-social, que acaba de ser descrito, e o local que, com suas características específicas, pode agravar o quadro de preocupações individuais. De qualquer modo, é neste último que tendem a ganhar concretude todas as outras preocupações.

Isso posto, cabe, agora, tentar identificar o que aconteceu na pesquisa relatada ao longo deste artigo. Como já foi visto, foram poucas as participantes desta pesquisa que mostraram ter consciência de que, em um mundo em mudança, as causas da incerteza e insegurança podem ser muitas e transcender o contexto local. Este foi o caso de Luciana da Silva, quando fez referência à "vida louca que a gente leva... de incertezas...”. Foi também o caso de Regina Ribeiro que, de modo análogo, se referiu a um "mundo meio doido". 
Na maior parte das vezes, no entanto, as apreensões conscientes das mães entrevistadas mostraram estar concentradas quase exclusivamente em uma única fonte local de inseguranças e preocupações: a dos riscos que a vida numa cidade violenta como o Rio de Janeiro deste início de milênio acarreta para seus filhos (é interessante observar que é infreqüente a menção a preocupações análogas com outros membros da família).

Para estes riscos não há proteção eficaz ou duradoura, elas sabem disso. Já para a apreensão que eles geram, há um antídoto eficaz do qual elas fazem muito uso: acompanhar a movimentação dos filhos à distância via celular. O novo significado que dão a "segurança" indica que o que começou, de fato, como uma medida para aumentar a segurança dos filhos (sem, no entanto, poder assegurá-la), acabou se tornando uma medida (muito eficaz) de combate à angústia das mães (a "segurança" de saber que seus filhos estão bem). Na grande maioria dos casos, o uso que fazem de "segurança" com o significado de tranqüilidade, bem-estar, sossego, etc. é tão estável, consistente, sistemático e pouco conflituoso que faz crer que esta palavra definitivamente agregou um novo domínio semântico, do qual sempre foi próxima, mas com o qual não se fundia.

Os celulares são os responsáveis por essa "segurança", na medida em que possibilitam que elas estejam constantemente em contato com os filhos, tornando-as, muitas vezes, presenças-ausentes em sua programação. Desse tipo de presença, essas mães ainda derivam o bônus psicológico do prolongamento da proximidade cotidiana com seus filhos já adultos.

Por esse motivo, mas, acima de tudo pelo fato dessa nova tecnologia lhes ter ofertado uma forma de aplacar suas angústias em relação a como estão os filhos durante sua deambulação diurna e principalmente noturna nesta cidade violenta, essas mães acham que a telefonia celular chegou em um bom momento. Para elas, os celulares são definitivamente um "presente do céu".

\section{Notas}

1 Agradeço o apoio dado pelo CNPq sob a forma de bolsa de produtividade em pesquisa, auxílio a projetos individuais de pesquisa e bolsas de Iniciação Científica.

\section{Referências}

Almeida, M. I. M., \& Tracy, K. M. A. (2003). Noites nômades: Espaço e subjetividade nas culturas contemporâneas. Rio de Janeiro, RJ: Rocco.

Bauman, Z. (1998). O mal-estar da pós-modernidade. Rio de Janeiro, RJ: Jorge Zahar. (Original publicado em 1997)

Bauman, Z. (2001). Modernidade líquida. Rio de Janeiro, RJ: Jorge Zahar. (Original publicado em 2000)

Beck, U. (1995). Autodissolução e auto-risco da sociedade industrial: O que isso significa? In U. Beck, A. Giddens \& S. Lash, Moder- nização reflexiva: Política, tradição e estética na ordem social moderna (pp. 207-218). São Paulo, SP: Editora da Universidade Estadual Paulista.

Castells, M., Fernández-Ardèvol, M., Qiu, J. L., \& Sei, A. (2007). Mobile communication society: A global perspective. Cambridge, MA: MIT Press.

Gergen, K. J. (2002). The challenge of absent presence. In J. Katz \& M. Aakhus (Eds.), Perpetual contact: Mobile communication, private talk, public performance (pp. 227-241). Cambridge, MA: Cambridge University Press.

Giddens, A. (2002). Mundo em descontrole. Rio de Janeiro, RJ: Record. (Original publicado em 1999)

Gottlieb, N., \& McLelland, M. (2003). The Internet in Japan. In N. Gottlieb \& M. McLelland (Eds.), Japanese cybercultures (pp. 1-16). London: Routledge.

Habuchi, I. (2005). Accelerating reflexivity. In M. Ito, D. Okabe \& M. Matsuda (Eds.), Personal, portable, pedestrian: Mobile phones in Japanese life (pp. 165-182). Cambridge, MA: MIT Press.

Ito, M., Okabe D., \& Matsuda, M. (2005). Personal, portable, pedestrian: Mobile phones in Japanese life. Cambridge, MA: MIT Press.

Katz, J. E., \& Aakhus, M. (2002). Introduction: framing the issues. In J. E. Katz \& M. Aakhus (Eds.), Perpetual contact: Mobile communication, private talk, public performance (pp. 1-13). Cambridge, MA: Cambridge University Press.

Labov, W. (1972). The logic of nonstandard English. In W. Labov. Language in the inner city (pp. 201-240). Philadelphia: University of Pennsylvania Press.

Leitão, C., \& Nicolaci-da-Costa, A. M. (2004). A psicologia no contexto mundial. Estudos de Psicologia (Natal), 8(3), 421-430.

Ling, R. (2004). The mobile connection: The cell phone's impact on society. San Francisco: Morgan Kaufmann.

Ling, R., \& Yttri, B. (2002). Hyper-coordination via mobile phones in Norway. In J. E. Katz \& M. Aakhus (Eds.), Perpetual contact: Mobile communication, private talk, public performance ( $\mathrm{pp}$. 139-169). Cambridge, MA: Cambridge University Press.

Lyon, D. (2001). Surveillance society: monitoring everyday life. Buckingham: Open University Press.

Miyaki, Y. (2005) Keitai use among Japanese elementary and junior high-school students. In M. Ito, D. Okabe \& M. Matsuda (Eds.), Personal, portable, pedestrian: Mobile phones in Japanese life (pp. 277-299). Cambridge, MA: MIT Press.

Nafus, D., \& Tracey. K. (2002). Mobile phone consumption and concepts of personhood. In J. E. Katz \& M. Aakhus (Eds.), Perpetual contact: Mobile communication, private talk, public performance (pp. 206-221). Cambridge, MA: Cambridge University Press.

Nicolaci-da-Costa, A. M. (2002). Revoluções tecnológicas e transformações subjetivas. Psicologia: Teoria e Pesquisa, 18(2), 193202.

Nicolaci-da-Costa, A. M. (2004a). Impactos psicológicos do uso de celulares: Uma pesquisa exploratória com jovens brasileiros. Psicologia: Teoria e Pesquisa, 20(2), 165-174.

Nicolaci-da-Costa, A. M. (2004b). A passagem interna da modernidade para a pós-modernidade. Psicologia: Ciência e Profissão, 24(1), 82-93.

Nicolaci-da-Costa, A. M. (2006). Celulares: A emergência de um novo tipo de controle materno. Psicologia \& Sociedade, 18(3), 88-96. 
Nicolaci-da-Costa, A.M. "Celulares: um 'presente do céu' para mães de jovens"

Nicolaci-da-Costa, A. M. (2007). O campo da pesquisa qualitativa e o Método de Explicitação do Discurso Subjacente (MEDS). Psicologia: Reflexão e Crítica, 20(1), 68-76.

Tomita, H. (2005). Keitai and the intimate stranger. In M. Ito, D. Okabe \& M. Matsuda (Eds.), Personal, portable, pedestrian: Mobile phones in Japanese life (pp. 183-201). Cambridge, MA: MIT Press.

Ana Maria Nicolaci-da-Costa é Coordenadora do Núcleo de Estudos sobre Tecnologia e Subjetividade (NETS), Professora Associada do Departamento de Psicologia da Pontifícia Universidade Católica do Rio de Janeiro (PUC-Rio), M.A. pela New School for Social Research, N.Y., EUA e Ph.D. pela University of
London. Endereço para correspondência: PUC-Rio Departamento de Psicologia, Rua Marquês de São Vicente, 225, Gávea, Rio de Janeiro, RJ, 22453-900. Tel.: (21) 35271183; Fax: (21) 35271187 anicol@psi.puc-rio.br

\section{Celulares: um "presente do céu"} para mães de jovens

Ana Maria Nicolaci-da-Costa

Recebido: 03/04/2007

$1^{\text {a }}$ Revisão: 28/08/2007

Aceite Final: 30/08/2007 